\title{
College Courses in County Jails: Pipedreams or Possibilities?
}

\author{
Mary Lyndon (Molly) Shanley, Vassar College
}

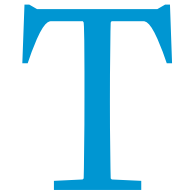
his article engages in unabashed advocacy. I call attention to opportunities for postsecondary education in county jails and want to persuade readers to consider offering college or pre-college courses there. Jail-based teaching is a benefit to those who take courses while incarcerated, useful to their communities as they receive returning citizens, and rewarding to the instructor and college students who may join in courses given in the jail.

First, an explanation of the difference between "jail" and "prison" in the United States is useful. Jails are under the jurisdiction of county governments and hold three categories of persons: those who have been arrested and are being held prior to plea bargain, trial, or sentencing; are sentenced to prison and awaiting transfer to a state facility; or are convicted of a misdemeanor and are serving a sentence of (typically) less than a year or 18 months. Prisons, by contrast, are run by the state (as well as the federal government) and hold people convicted of a felony who typically are serving a sentence longer than a year. Most of the attention to college opportunities for incarcerated persons has been on prisons; while jails offer courses that lead to a high school equivalency degree (i.e., HSE or GED), the short length of stay makes it difficult to design and offer college courses. However, it is possible and eminently worthwhile.

I have taught in both prison and jail. I began my work with incarcerated students when I taught a credit-bearing college course in a state medium-security women's prison, with 12 incarcerated students and 10 students from Vassar College together in the classroom. (This arrangement often is called "inside-out," "mixed," or "blended" classroom.) At about the same time, I began volunteering at my county jail, leading an informal weekly women's writing group in which women keep journals and read aloud something they have written during the preceding week. When I retired from Vassar, I developed a non-credit, 6-week-long academic class in the jail emphasizing analytical rather than personal writing. I became convinced of the value of offering postsecondary work, but the difficulties stemming from the short length of stay and a shortage of programming space and supervisory jail personnel seemed to make anything other than an informal class beyond reach. I contacted other academicians around New York State who are teaching in jails, and they confirmed the difficulty-and the rewards-of offering college courses in jails. (Because there are more than 3,0oo county jails in the United States-each of which has some autonomy over programming in the facility-I confined my research to what I could learn about programs in New York; see the endnotes.)
A number of workable models emerged from these conversations, and I hope that by describing the possibilities, I will inspire others to make college education part of programming in jails across the United States.

\section{DISTINCTIVE FEATURES OF JAIL-BASED COLLEGE PROGRAMS}

Two significant differences between teaching in state prisons and county jails are (in most cases) the location of the facility and the average length of stay of those incarcerated.

\section{Geographical Proximity and Community Ties}

People housed in a county jail generally are from the community or region in which the jail is located, as are many of the correction officers. (It is not uncommon to find that a correction officer and an incarcerated person know one another from middle or high school.) Some in the jail will be sent to a state prison, but many will return to the community directly from jail. This is markedly different from state prisons, where those who are incarcerated may have lived and committed their crimes hundreds of miles away and will return to those other communities.

Some of the satisfaction of teaching in jail stems from the jail's location in the community in which one lives and works. In my case, work in the jail has deepened my knowledge of and ties to the community. When discussions about social services, the dearth of affordable housing, the opioid crisis, the availability of mental-health and addiction treatment, gun violence, styles of policing, and workings of the court system arise, they are rife with specific local detail. (Not all exchanges focus on problems: I also learn about parks, bike trails, and performance venues that I have not yet explored.) Unlike prison classrooms, where students come from all parts of that state, or on campus, where students come from across the country and around the globe, my students in the jail reside in the same community, city, and county as I do, and our (different as well as similar) experiences in those communities illuminate discussions of citizenship and social wellbeing.

The jail's location in the community also has made me increasingly knowledgeable about and involved in reentry programs because these are essential to my students' future success. I have developed new ties to those working in social services, criminal justice, and community development.

Teaching in a county jail can help to bridge the gulf that often exists between campus and community. Offering courses can help make the jail itself, the problems that lead people to wind up in jail, and the opportunities for productive reintegration into the community more visible. 
The experience often leads college students to volunteer work or internships at local agencies. The insight they gain into the demographics of poverty, the effects of the dearth of jobs and housing, and the vagaries as well as the potential of county government and jail administration also suggest research topics and projects for a variety of courses. The threeway collaboration among jail, college or university, and reentry programs benefits all of these institutions.

\section{Relatively Short Length of Stay}

Compared to prison populations, those in jail are there for a relatively short stay, usually three to 18 months. Therefore,

\section{Length of the Course, Credit-Bearing or Non-Credit, Level of Course}

The length of the course, the academic level, and whether the course will be credit-bearing are closely related and raise issues distinct from those in prison teaching. Although prison courses vary considerably in content and structure, they tend to adhere to the model offered in US colleges and universities: they are usually semester-long (around 13 weeks); students are tested or otherwise screened for admission; class members are evaluated on the basis of class participation, papers, and/or exams; and courses range from introductory to advanced. Some programs offer a limited number of courses; others

\section{Some of the satisfaction of teaching in jail stems from the jail's location in the community in which one lives and works... When discussions about social services, the dearth of affordable housing, the opioid crisis, the availability of mental-health and addiction treatment, gun violence, styles of policing, and workings of the court system arise, they are alive with specific local detail.}

few academically eligible people can complete a traditional semester-long course. In thinking about establishing a college course, one must consider courses of shorter length, appropriate academic level, and whether the course should be credit-bearing or non-credit. I discuss these issues in greater detail in the section on "Practical Considerations" below.

The short length of stay not only shapes the type of course that can be offered but also influences students' state of mind and psychological readiness for academic work. Unlike people in prison who enroll in college courses after serving several years of a (sometimes lengthy) sentence, the person in jail has been arrested recently and is only just coming to terms with what has happened. Some are accused of serious felonies, others of minor infractions. Whereas some are serving relatively short sentences, those who are awaiting trial face uncertainty concerning the future: What, exactly, will they be charged with? Will they be found guilty? What will their sentence be? Where will they serve their term? How will their family react? For parents, who will take care of their children? Myriad other questions that have already been answered for those in state prison are unresolved sources of stress for those in jail; while those who enter the classroom bear this burden, they also focus on the work as a way to leave aside those concerns for a brief period. Some jails have a "post-sentencing" housing unit and, because it is known how long someone serving a sentence will be in the jail, it is easier to offer college and other reentry programs there than to an undifferentiated population.

\section{PRACTICAL CONSIDERATIONS IN DEVISING A COLLEGE COURSE FOR A COUNTY JAIL}

Those who are thinking of setting up such a program must be creative in coordinating the institutional missions and constraints of both the jail and their academic institution. enable students to earn college degrees. Because most people in a county jail will be there between three and 18 months, semester-long courses (i.e., 13 to 16 weeks) severely limit how many can enroll in and complete a course. Although semesterlong courses are not unknown, other formats usually make teaching college courses in jail more feasible.

Despite the difficulties created by a short and often unpredictable length of stay, the "blended-classroom" model often used in prison teaching-that is, bringing in students from campus to study alongside incarcerated students-is possible. Some schools address the 13-week-long semester by enrolling incarcerated students even when there is no guarantee that they will be able to finish. One model gives academic credit to college students and a certificate of completion to incarcerated students. ${ }^{1}$ Some give credit to incarcerated students who complete the semester's work and allow others to drop the course without penalty when released or transferred, and some instructors permit those who leave in the latter part of the semester to submit remaining work while outside. ${ }^{2}$ One university offers a course that has multiple sections, one of which is taught in jail, and allows a student released from jail before the end of the semester to enter a section of the same course that is offered on campus. ${ }^{3}$ Another allows students taking a literature course on campus to choose to participate in a weekly discussion group about their assigned books with incarcerated students in lieu of writing an essay; only the campus students receive course credit. 4 Although in all of these models the number of incarcerated students participating in the course inevitably decreases as the semester progresses, by all accounts both campus-based and incarcerated students benefit enormously from the readings and class discussions.

A university also could address the short length of stay by offering six-week-long courses in jail, making it more possible to enroll incarcerated students able to complete the course. 
Another approach gives field-work or community-based learning credit to students from campuses that participate in activities at the jail-for example, running a book club, currentaffairs discussion group, or resumé-preparation workshop, or tutoring people studying for their HSE degree. 5 Other
When outside students enter the jail as part of a field-work or community-based learning program, there is little cost to the university other than transportation from campus to jail. Materials for incarcerated students sometimes are paid for by the college, sometimes by the jail from commissary funds.

\section{A first step for those interested in teaching a college course in a county jail is to speak to the jail administrator and the program officer to find out what other programs are currently offered; explain why you want to offer a college course(s); and ask for their thoughts, observations, and advice.}

programs might offer postsecondary academic work without the structure of a semester- or half-semester course, using advanced or graduate students as facilitators. ${ }^{6}$

It also is possible to offer courses that bring only the professor into the jail as a course overload for the faculty member or on a volunteer basis. At least one community college in New York State offers several six-week-long credit-bearing courses paid for by a fund created from commissary profits. ${ }^{7}$

The short length of stay also affects the academic level of courses offered in jail. Prison programs in which incarcerated students can take courses over many years offer introductory, intermediate, and advanced classes. However, the short length of stay in jail means that although the intellectual ability of many of those in jail is quite high-even when they haven't had much formal academic training-jail courses are usually at the introductory level.

\section{Selection of Students}

Prison and jail personnel often select participants for college courses because they may be familiar with the level of readinessboth intellectual and behavioral-of potential students. In prison programs, selection often is done through exam. Outside students enroll for the course as they would for an on-campus course.

\section{Financing a Program}

Paying for postsecondary credit-bearing classes in jail is relatively easy when the course is offered using the "blended" or "mixed-population" classroom model. These courses are simply part of the faculty members' regular teaching load and their salaries are paid by the university. Teaching in prison and jail also can be attractive to emeriti professors who are paid on a per-course basis. Private colleges and universities usually waive tuition for the incarcerated students. Public universities (including community colleges) in some states are not permitted by law to waive tuition. However, at least two jails in New York pay tuition for incarcerated students from profits from commissary sales that state law stipulates "shall be utilized only for purposes of prisoner welfare and rehabilitation." ${ }^{8}$ Support for non-volunteer faculty and for books and other course materials for incarcerated students may come from donations, a fund at the university, or jail funds designated for inmate programming.

\section{Proposing a College Program to Jail and University Administrators}

A first step for those interested in teaching a college course in a county jail is to speak to the jail administrator and the program officer to find out what other programs are currently offered; explain why you want to offer a college course(s); and ask for their thoughts, observations, and advice. The most vibrant programs in jails in New York State are in facilities where the jail administrator or program officer is committed to and supportive of the courses. Other facilities balk at the additional work that new programming entails, the added demands on security personnel, and the dearth of space. Jail administrators typically operate with greater autonomy than superintendents of state prisons, who are bound by regulations handed down by the state Department of Corrections; therefore, finding sympathetic and receptive people in the sheriff's office and the jail is the point of entry.

Jail personnel will be particularly interested in the beneficial effect that a college class has on behaviors within the jail, recidivism rates, and cost. Point out that studies of the effects of postsecondary educational programs in prisons have shown that incarcerated persons are less likely to be disruptive or violent when they are actively engaged in a program, resulting in improved safety for inmates and staff alike. This means lower costs for prison security, medical services, and workers' compensation. Educational programs in prison also affect post-prison behavior in ways that enhance the safety of the larger community and provide economic benefit. Increased employment rates and wages are correlated with reduced recidivism, along with greater income and sales-tax revenues. ${ }^{9}$ Educational programs in jail would generate the same net savings to society in the long run as those in prisons.

Communication and negotiation with the university or college also is part of the process of undertaking jail teaching. On the blended-classroom model, if a faculty member teaches a course that is part of the regular teaching load, there are few costs other than the number of enrolled students perhaps being smaller than usual (10-12 is typical) and the cost of a university van to take them to the jail. Supervising field-work or community-based learning programs and activities that are a component of a course are part of faculty members' normal teaching load. The educational benefit of their exposure to the criminal-justice system and the diversity of experiences and 
perspectives that students will encounter in the jail classroom will spread to other students through informal conversations and class discussions.

\section{COLLEGE COURSES, COUNTY JAILS, AND RETURNING CITIZENS}

Collaboration to make postsecondary education in jails effective over the long run ideally will involve private and public universities and colleges, jails, and reentry organizations; enrollment in a community college at reentry will be a goal for some. Coordination with reentry programs also will increase the impact of any jail-based educational program. For example, someone taking a course in jail could follow that by enrolling in a job-readiness and college-readiness course offered by a reentry organization. Reentry counselors could then guide returning citizens to admissions and financial-aid offices at the community college. ${ }^{10}$ The benefits and pleasures of offering jail-based college courses amply repay the work involved. When university faculty and administration and jail administrators and program officers share a commitment to expanding educational opportunities for those incarcerated, extraordinary programs emerge.

\section{NOTES}

1. For example, the State University of New York (SUNY)-Potsdam offered a course in applied theater arts at St. Lawrence County Correctional Facility (SLCCF), in which SUNY students received credits and incarcerated students did not; the course will be credit-bearing for all in the future. Available at www.potsdam.edu/academics/AAS/Theatre/cultivatinghumanity. St. Joseph's College, Long Island, offers courses at Riverhead Jail with credit for outside students and certificates of participation and completion for incarcerated students. Available at www.sjcny.edu/long-island/academics/programsdepartments/criminal-justice/inside-out.

2. Every semester for the past two years, St. John's University has offered a semester-long course on Rikers Island (i.e., New York County's jail) All students who complete the course earn three credits. Incarcerated students transferred or released before mid-semester may drop the course; those released later but before the end of the semester may-at the instructor's discretion-complete remaining written work on the outside to receive course credit. Available at www.stjohns.edu/about/news/2017-10-05/ students-focus-criminal-justice-system-inside-out; personal communication, Professor Judith Ryder, Department of Sociology and Anthropology, St John's University (April 12, 2018). Manhattan College also offers semesterlong credit-bearing courses on Rikers Island and in Westchester County Jail, and encourages formerly incarcerated students from those courses to apply to the college after their release. Available at www.americamagazine.org/ issue/prison-class, and https://www.midhudsonnews.com/News/2018/July/ 14/WCJ_ManCol-14Jul18.html.

3. In SUNY-Potsdam's credit-bearing course at SLCCF, a student released before completing the course may enter another section taught on campus or, at the instructor's discretion, do independent work that enables the student to receive credit. Personal communication, Professor Nancy Lewis, Department of Sociology, SUNY-Potsdam (April 10, 2018).

4. Nazareth College in Rochester does this in collaboration with Monroe County Correctional Facility. Available at www2.naz.edu/stories/free-yourmind; www.facebook.com/monroesheriffny/photos/a.164532256924757.353 91.149100528467930/1125692084142098/?type $=3$.

5. St. Lawrence University students engage in a variety of programs with incarcerated students at SLCCF through the university's communitybased learning program. Available at www.stlawu.edu/community-basedlearning/st-lawrence-county-correctional-facility and www.stlawu.edu/ community-based-learning/news/faculty-spotlight-liz-regosin. Students at SUNY-Potsdam engage in tutoring and other academic activities at SLCCF through a service-learning program. Personal communication, Professor Nancy Lewis, Department of Sociology, SUNY-Potsdam (April 10, 2018).

6. For example, Columbia University's Justice-in-Education Initiative offers several four- to six-week-long non-credit courses for incarcerated young adults on Rikers Island, funded by a grant from the Mellon Foundation. Available at http://centerforjustice.columbia.edu/education/justice-educationinitiative.

7. Monroe Community College (MCC) offers two six-week-long creditbearing courses at Monroe County Correctional Facility. These courses enroll only students from within the facility, and the jail pays MCC using jail funds designated for inmate programs. Available at www2. monroecounty.gov/sheriff-jailbureauprograms.

8. Available at https://govt.westlaw.com/nycrr/Document/I4fb29b3ccd1711dda $432 \mathrm{a} 117 \mathrm{e} 6 \mathrm{eof} 345$ ?view Type $=$ FullText \&origination Context $=$ documenttoc \& transition Type $=$ CategoryPageItem \& contextData $=$ (sc.Default $)$.

9. One research study drawing on data from 16 educational programs from various states found that program participants were twice as likely to be employed after release as inmates who did not participate. From Cellblocks to Classrooms: Reforming Inmate Education to Improve Public Safety, Report of California Legislative Analyst's Office. Available at www.lao.ca.gov/2008/ crim/inmate education/inmate education_021208.aspx; see also Lois M. Davis et al, Evaluating the Effectiveness of Correctional Education: A MetaAnalysis of Programs That Provide Education to Incarcerated Adults (Santa Monica, CA: RAND Corporation 2013). Available at www.rand.org/pubs/ research_reports/RR266.html.

10. Although it is not a college course, Tompkins County sponsors College Initiative Upstate (CIU), a bridge-to-college program that is part of the reentry organization Opportunities, Alternatives \& Resources. Volunteer academic counselors meet with groups inside and outside of the jail to provide academic counseling and assistance in college-application and financial-aid forms. CIU works in close collaboration with county government and Tompkins Cortland Community College and is currently funded by private donations. Available at www.oartompkins.org/collegeinitiative-upstate. 